\title{
Hair Growth Promoting Activity of Nothopanax scutellarium Merr. Leaves
}

\author{
Via Rifkia','Mahdi Jufri',Abdul Mun'im²* \\ ${ }^{1}$ Graduate Program of Herbal Medicine, Faculty of Pharmacy, Universitas Indonesia, Depok 16424, West Java, INDONESIA. \\ 2Department of Pharmacognosy-Phytochemistry, Faculty of Pharmacy Universitas Indonesia, Depok 16424, West Java, INDONESIA.
}

\begin{abstract}
Objective: The aims of this study were to know the safety using Hen's eggs-chorioallantoic membrane (HET-CAM) test method and hair growth promoting activity of the ethyl acetate fraction of Nothopanax scutellarium leaves. Methods: Safety test was measured by scoring and categorizing irritation onHET-CAM. Meanwhile, activity test was conducted by applying the hair tonic of the ethylacetate fraction on the back of the rabbits, and the length of hair was measured in the $1^{\text {st }}, 2^{\text {nd }}$ and $3^{\text {rd }}$ week.In the $3^{\text {rd }}$ week, the hair growth was weighed and hair diameter also was measuredusing scanning electron microscope (SEM). Results: The result showed that 0.2 gram of ethyl acetate fraction of N.scutellarium leaves have mild irritation effect, whereas the formulation contained with $0.5 \%$ and $1 \%$ of fraction increased hair growth and hair diameter. Conclusion: The ethyl acetate fraction of N. scutellarium
\end{abstract}

have mild irritan effect, and the hair tonic demonstrated hair growth promoting activity.

Key words: Hair Tonic, Hair Growth Activity, Nothopanax scutellarium, Safety, HET-CAM.

\section{Correspondence :}

Abdul Mun'im, Department of Pharmacognosy-Phytochemistry, Faculty of Pharmacy Universitas Indonesia, Depok 16424, West Java, INDONESIA.

Phone no: +62 8111184550

Email: abdul.munim61@ui.ac.id

DOI: 10.5530/jyp.2017.9.85

\section{INTRODUCTION}

Hair loss and thinning are common problems that found in term of clinical dermatology. There are a number of products of hair tonic that claimed to increase hair growth, either using natural products or synthetic compounds. Some studies also reported the prospect of the natural product for hair growth promoting. ${ }^{1-3}$ There has been no report on its main active ingredient responsible for the hair growth activity. In the current work, cedrol as a major constituent from $P$. orientalis was evaluated for its potential on hair growth in vivo, different concentration of cedrol $(10,20$ and $30 \mathrm{mg} / \mathrm{mL})$ promoted hair growth in a dose-dependent manner. ${ }^{2}$ Nothopanax scutellarium Merr from Araliace family is the tropical plant. The leaves were traditionally known to have hair growth promotion activity. ${ }^{4}$

Based on previous research, ethanolic extract of the leaves was proven to have hair growth activity. However, the results of studies showed that hair growth activity of the ethanolic extract was lower than Minoxidil. ${ }^{5}$ Another study, the combination of ethanolic extract of the leaves with ethanol extract of tea leaves, also resulted in lower hair growth activity than positive control. ${ }^{6}$ Some studies reported that flavonoid demonstrated hair growth promoting activity. ${ }^{7,89}$ To increase hair growth activity of leaves extracts from N. scutellarium, further fractionation process was needed using the suitable solvent to increase the level of flavonoids, which required in increasing hair growth. Ethyl acetate was chosen as a solvent for a fractionation process of $N$. scutellarium leaves.

This study presented the safety test of the ethyl acetate fraction of $N$. scutellarium leaves using HET-CAM (Hen's Egg Test - chorioallantoic membrane) method. Then, the hair tonic formula of the fraction on hair growth activity was performed in rabbits.

\section{MATERIALS AND METHODS}

\section{Materials}

The leaves were obtained from the Indonesian Spice and Medicinal Crops Research Institute (ISMCRI), Bogor, and authenticated in Botany Herbarium Research Institute, Cibinong, West Java. The voucher specimen was deposited in Herbarium of Pharmacognosy, Faculty of Pharmacy, Universitas Indonesia. Solvents (ethanol, ethyl acetate, n-hexane), nipagin, nipasol, sodium metabisulfite, propylene glycol, chorioallanthoic membrane (CAM), and minoxidil as the positive control were purchased from local suppliers.

\section{Extraction and Fractionation}

The leaves powder $(4 \mathrm{~kg}$ ) were macerated with ethanol (40L). Solvents were filtered and concentrated using rotary vacuum evaporator at $50^{\circ} \mathrm{C}$. The ethanolic extract was dispersed in water and partitioned with nhexane and ethyl acetate, subsequently. The ethyl acetate phase was concentrated using a rotary vacuum evaporator at a temperature of $50^{\circ} \mathrm{C}$ to give a viscous fraction of ethyl acetate. Total flavonoid of the extract was determined by $\mathrm{AlCl}_{3}$ according to Kabir et al, 2016 with slight modification. ${ }^{10,11}$

\section{Safety test by HET-CAM method}

The HET-CAM bioassay was performed to evaluate the level of irritation on mucous membrane based on slight modification of Steiling method. ${ }^{12}$ Briefly, the fraction $(0.2 \mathrm{~g})$ solution was applied to chorioallantoic membrane (CAM) and left for 20 seconds until the sample was spread smooth. Then, the membrane was evaluated within 5 minutes to notice any symptoms of hemorrhage, lysis, and/or coagulation. The evaluation determined based on the result of scores and category of irritation (Table 1). The results of irritation scores can be calculated using the following equation: 
where:

Hemorrhage time $=$ time (in seconds) of the first appearance of blood hemorrhages.

Lysis time $=$ time (in seconds) of the first appearance of vessel lysis.

Coagulation time $=$ time (in seconds) of the first appearance of protein coagulation.

\section{Formulation of hair tonic}

Formulation of hair tonic prepared the variation of concentration of eth$\mathrm{yl}$ acetate fraction the leaves. The calculation of the percentage composition of each hair tonic can be seen in Table 2. Nipagin and nipasol were dissolved in ethanol, while sodium metabisulfite was dissolved in distilled water. Both solutions were mixed, and ethyl acetate fraction of $N$. scutellarium leaves was added into solution. Propylene glycol was added until the desired volume. All material were stirred until homogenously mixed.

\section{Evaluation of hairtonic}

Evaluation of hair tonic preparations was conducted by observing the color and odor during storage. Furthermore, examination of $\mathrm{pH}$ by using a $\mathrm{pH}$ meter and hair tonic stability test at low temperature $\left(4^{\circ} \pm 2^{\circ} \mathrm{C}\right)$, room temperature $\left(25^{\circ} \pm 2^{\circ} \mathrm{C}\right)$, and high temperature $\left(40^{\circ} \pm 2^{\circ} \mathrm{C}\right)$ for 12 weeks by observing organoleptic appearance and $\mathrm{pH}$ every 2 weeks. ${ }^{15,16}$

\section{Hair growth activity}

White male rabbits of New Zealand strain (4-5 months, with weights ranging from 2-4 kg) were obtained from Indonesia Research Institute of Animal Production (IRIAP). The study was approved by the Ethical Committee, Faculty of Medicine, Universitas Indonesia (No.683/H2.F1/ ETIK/2012).

Table 1: Scores and category of irritation

\begin{tabular}{cc}
\hline Scores on HET-CAM & Category of irritation \\
\hline $0-0.9$ & Nonirritant or practically no irritation \\
$1-4.9$ & Weak or slight irritation \\
$5-8.9$ & Moderate irritation \\
$9-21$ & Strong or severe irritation \\
\hline
\end{tabular}

Table 2: The percentage of hair tonic ingredients

\begin{tabular}{cccccc}
\hline & \multicolumn{5}{c}{ Concentration (\%) (w/w) } \\
\cline { 2 - 6 } Ingredients & $\begin{array}{c}\text { Negative } \\
\text { control } \\
(\%)\end{array}$ & $\begin{array}{c}\text { Formula I } \\
(\%)\end{array}$ & $\begin{array}{c}\text { Formula } \\
\text { II (\%) }\end{array}$ & $\begin{array}{c}\text { Formula } \\
\text { III (\%) }\end{array}$ & $\begin{array}{c}\text { Positive } \\
\text { control } \\
(\%)\end{array}$ \\
\hline $\begin{array}{c}\text { The ethyl } \\
\text { acetate fraction } \\
\text { Minoxidil }\end{array}$ & - & 0.25 & 0.5 & 1 & - \\
$50 \%$ ethanol & 60 & 60 & 60 & 60 & 60 \\
Propylene & 2 & 2 & 2 & 2 & 2 \\
glycol & 0.02 & 0.02 & 0.02 & 0.02 & 0.02 \\
Sodium & & - & - & - & 2 \\
metabisulfite & 0.01 & 0.01 & 0.01 & 0.01 & 0.01 \\
Nipagin & 0.02 & 0.02 & 0.02 & 0.02 & 0.02 \\
Nipasol & 37.95 & 37.70 & 37.45 & 36.95 & 35.95 \\
\hline Aquadest & & & & &
\end{tabular}

Four white male rabbits were used to examine hair growth activity. The hair on the back of the rabbit was shaved and divided into 6 areas with size of $4 \times 4 \mathrm{~cm} ; 3$ areas on the left side, and another 3 areas on the right side with $2 \mathrm{~cm}$ distance of each area. Table 3 showed the treatment of samples. Hair tonic was applied in the shaved areas and observed for 3 weeks. During the experiment the hair growth was observed at week 1, 2, and 3 , the 10 longest rabbit hair removed in each test area and measured using calipers. ${ }^{17}$ At the end of the application hair weight of rabbits were determined by pulling hair that grows on the test area and then weighed. The hair diameter was observed at week 3 by using SEM (Scanning Microscope Electron).

\section{Statistical analysis}

Data were reported as mean \pm standard deviation. Statistical analyses were performed using Student's t-test for the significance of the results $(\mathrm{P}<0.05)$.

\section{RESULTS}

\section{Fractionation}

The result of fractionation that used in the preparation of hair tonic was ethyl acetate fraction. Characteristics of ethyl acetate fraction are shown in Table 4. The fraction contained total flavonoid $4.79 \%$.

\section{Safety test by HET-CAM method}

Table showed the results of HET-CAM test. The irritation score of he test fraction is 4.54 , indicated mild irritation on chorioallantoic membranes (Table 5).

Table 3: Treatment of rabbits

\begin{tabular}{ccc}
\hline Area & Group & Treatment \\
\hline I & Normal control & Saline solution \\
II & Negative control & Hair tonic preparations containing no the ethyl \\
acetate fraction
\end{tabular}

Table 4: Characteristics of the ethyl acetate fraction

\begin{tabular}{cc}
\hline Characteristics of ethyl acetate fraction \\
\hline Organoleptic & Color: Dark green \\
& Odor $:$ Odorless typical \\
\hline
\end{tabular}




\section{Evaluation of hair tonic}

On this study, the stability test conducted by accelerated stability test. The results of organoleptic consisted of observations color and odor of hair tonic of the ethyl acetate fraction stored at low temperature $\left(4^{\circ} \pm 2^{\circ} \mathrm{C}\right)$, room temperature $\left(25^{\circ} \pm 2^{\circ} \mathrm{C}\right)$, and high temperature $\left(40^{\circ} \pm 2^{\circ} \mathrm{C}\right)$ looks stable. Results of hair tonic $\mathrm{pH}$ measurement of the fraction of ethyl acetate did not change significantly at low temperatures $\left(4^{\circ} \pm 2^{\circ} \mathrm{C}\right)$, room temperature $\left(25^{\circ} \pm 2^{\circ} \mathrm{C}\right)$ and high temperature $\left(40^{\circ} \pm 2^{\circ} \mathrm{C}\right)$ for 12 weeks of storage.

\section{Effectivity of hair growth}

The results showed that there were significant differences among groups. After observation for 3 weeks, the resulting hair growth on the groups of formula II containing fraction of test of $0.5 \%$ and formula III containing the fraction of test of $1 \%$; has faster hair growth activity (Figure 1).

\section{Hair length}

The result of measurement of hair length of rabbit at week 1 shows the average on the groups of normal control, negative control, the formula I, formula II, formula III, and positive control respectively are 4.72 $\mathrm{mm}, 4.80 \mathrm{~mm}, 8.39 \mathrm{~mm}, 10.48 \mathrm{~mm}, 12.37 \mathrm{~mm}$, and $9.16 \mathrm{~mm}$. Furthermore, the results of the statistical analysis showed that the average hair length rabbit of each treatment group there were significant differences $(\mathrm{p}<0.05)$.

At week 2, the average of hair length rabbit on the groups of normal control, negative control, the formula I, formula II, formula III, and positive control respectively are $8.10 \mathrm{~mm}, 8.13 \mathrm{~mm}, 12.09 \mathrm{~mm}, 14.29 \mathrm{~mm}$, $18.24 \mathrm{~mm}$, and $13.78 \mathrm{~mm}$. The results of statistical calculation show the average hair length rabbit of each treatment group there were significant differences $(\mathrm{p}<0.05)$. At week 3 , the average of hair length rabbit on the groups of normal control, negative control, formula I, formula II, formula III, and positive control respectively are $12.33 \mathrm{~mm}, 12.35 \mathrm{~mm}$, $16.25 \mathrm{~mm}, 18.36 \mathrm{~mm}, 28.25 \mathrm{~mm}$, and $17.24 \mathrm{~mm}$. The result of statistical calculation shows the average hair length rabbit of each treatment group there were significant differences $(\mathrm{p}<0.05)$. Based on results of calculation of average hair length rabbits show formula II and formula III has faster activity of hair growth than the positive control (Figure 1). The re-

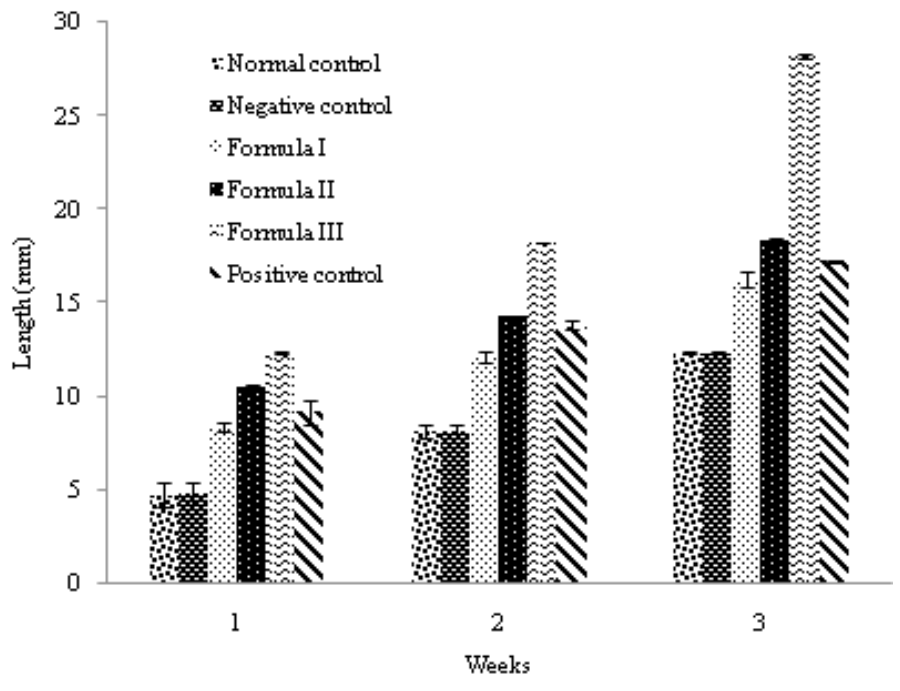

Figure 1: Effect of treatment on the average of hair length $(\mathrm{mm})$. sult of statistical calculation shows the average hair length rabbit of each treatment group there were significant differences $(\mathrm{p}<0.05)$.

\section{Hair weight}

The result of average of hair weight at normal control group, the negative control, formula I, formula II, formula III, and positive control each is $56.02 \mathrm{mg} / \mathrm{cm}^{2}, 55.86 \mathrm{mg} / \mathrm{cm}^{2}, 70.28 \mathrm{mg} / \mathrm{cm}^{2}, 73.02 \mathrm{mg} / \mathrm{cm}^{2}, 84.25 \mathrm{mg} /$ $\mathrm{cm}^{2}$, and $71.18 \mathrm{mg} / \mathrm{cm}^{2}$. The results of average hair weight indicated that that test area which is given formula II and formula III containing eth$\mathrm{yl}$ acetate fraction of $N$. scutellarium leaves $0.5 \%$ and $1 \%$ had a greater weight than positive control (Figure 2). There was significant difference in each treatment $(\mathrm{p}<0.05)$.

\section{Hair diameter}

The results of average rabbit's hair diameter show that the formula II and formula III containing of $0.5 \%$ and $1 \%$ ethyl acetate fraction of Nothopanax scutellarium leaves, respectively, has a larger diameter than the positive control (Figure 3). In addition to the observation of hair diameter, morphology hair of rabbit also was observed by SEM. The results show that the morphology hair of rabbit in the groups of formula II and formula III has composed regularly of hair cuticle and overlap, which consists of layers of flat keratin (Figure 4).

\section{DISCUSSION}

In this study, fractionation is conducted to increase the levels of flavonoids of Nothopanax scutellarium leaves, which believed to have potential activity of hair loss and thinning treatment. Flavonoid has been reported to have some pharmacological activities, such as antioxidant, hepatoprotective and anticancer. ${ }^{18,19,20}$ Based on several studies, a compound that plays a role in hair growth activity are proanthocyanidin compounds and procyanidin. ${ }^{8,21}$ One of the mechanisms hair growth promoting through Endothelial nitric oxide synthase (eNOS). Daidzein, genistein, isorhamnetin, kaempferol, quercetin, naringenin, and pelargonidin inhibited iNOS protein and mRNA expression and also nitric oxide (NO) production. ${ }^{16}$ Myricetin, quercetin, baicalein and fisetin demonstrated hair growth activity via inhibition of the type I $5 a$-reductase. ${ }^{22}$

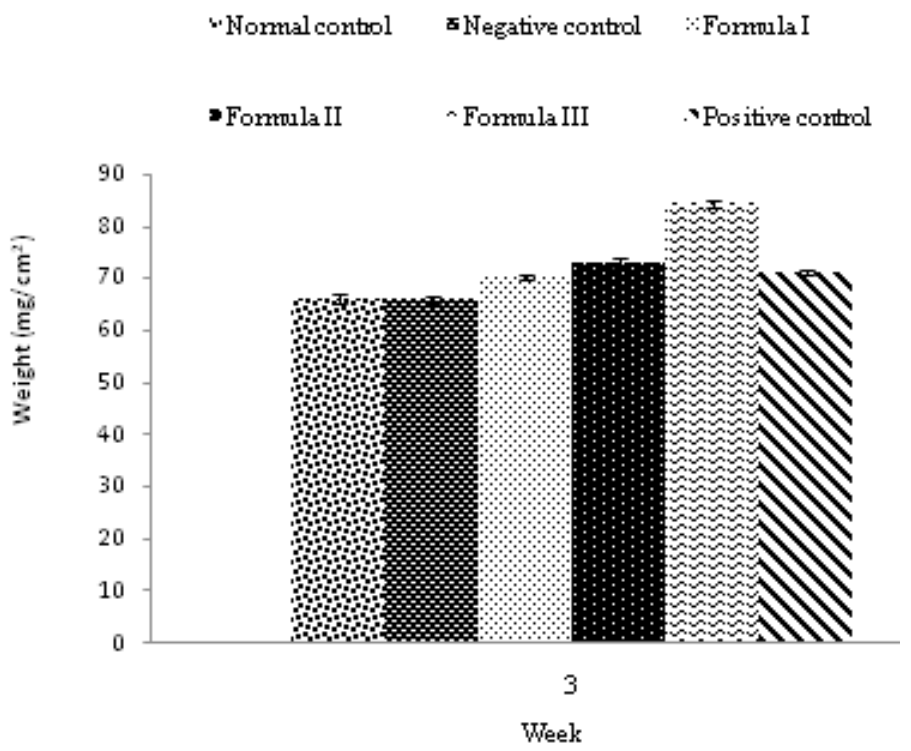

Figure 2: The average of hair weight $(\mathrm{mg} / \mathrm{cm} 2)$ of rabbit $A, B, C$, and $D$ at the end of experiment. 
Table 5: The result of average score and category of irritation

\begin{tabular}{ccc} 
Sample & $\begin{array}{c}\text { Average of } \\
\text { Irritation } \\
\text { score }\end{array}$ & Category of irritation \\
\hline $\begin{array}{c}\text { Negative control : } \\
0.9 \% \mathrm{NaCl} \text { solution }\end{array}$ & 0 & $\begin{array}{c}\text { Nonirritant or practically no } \\
\text { irritation }\end{array}$ \\
$\begin{array}{c}\text { Positive control : } 1 \% \mathrm{SLS} \\
\text { Fraction of test: ethyl } \\
\text { acetate fraction of } \mathrm{N} . \\
\text { scutellarium leaves }\end{array}$ & 10.23 & Strong or severe irritation \\
\hline
\end{tabular}

$\begin{array}{lll}\because \text { Hormal control } & \text { qHegative control } & \therefore \text { Formula I } \\ \text { - Formula II } & \because \text { Formula III } & \text { Positive cortrol }\end{array}$

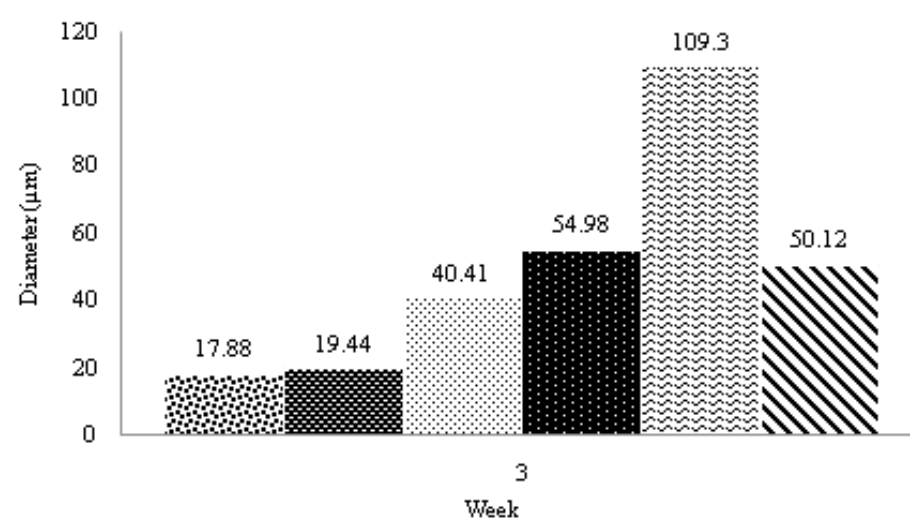

Figure 3: The average of rabbit hair diameter $(\mu \mathrm{m})$ at the end of experiment.

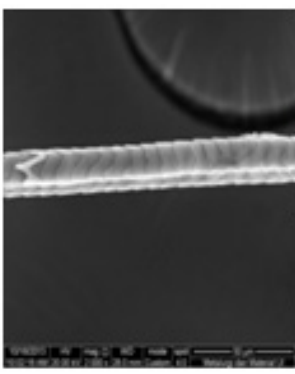

(a)

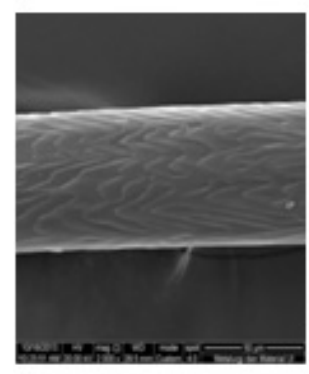

(d)

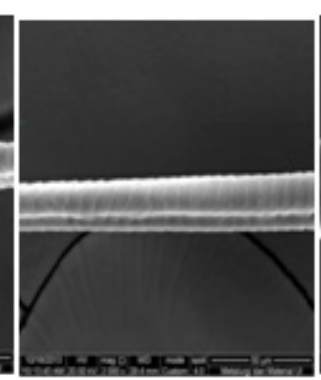

(b)

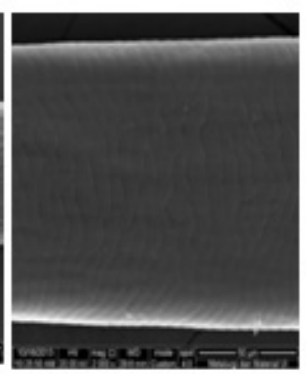

(e)

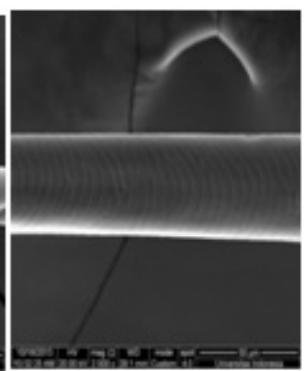

(c)

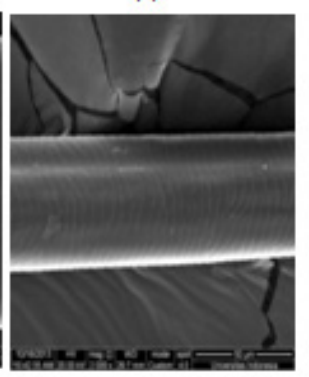

(f)
Figure 4: Scanning Microscope Electrone magnification: x2000. (a) normal control; (b) negative control; (c) formula I; (d) formula II; (e) formula III; (f) positive control.
Evaluation of irritation level was performed by using the HET-CAM method determined by the score and category irritation by comparing the changes in the chorioallantoic membrane between the negative control, positive control and fractions test. Results showed that there was a difference between the positive control (1\%SLS) with test fractions containing ethyl acetate fraction of N. scutellarium leaves (Table 5). In some studies, testing by the HET-CAM method has been done especially for plants that can be developed into cosmetic products, such as plants of Lansium domesticum and Phyllantus niruri. Both of these plants has efficacy as an antioxidant and antityronase. Based on the previous study, at a concentration of $2.5 \%$ either extract of Lansium domesticum or extract of Phyllanthus niruri cause moderate irritation of chorioallantoic membranes. ${ }^{23}$

In this study, we used the ethyl acetate fraction as an active compound of the hair tonic formulation. This formulation was evaluated by observing the color, odor, $\mathrm{pH}$, and stability of the hair tonic stored at low temperature $\left(4^{\circ} \pm 2^{\circ} \mathrm{C}\right)$, room temperature $\left(25^{\circ} \pm 2^{\circ} \mathrm{C}\right)$, and high temperature $\left(40^{\circ} \pm 2^{\circ} \mathrm{C}\right)$ for 12 weeks with a method of accelerated stability. The results showed hair tonic stable during storage. A product which stabile in accelerated stability tests, that the that is stable in storage at room temperature for one year. ${ }^{24}$ Meanwhile, result of observations showed a hair tonic $\mathrm{pH}$ has a $\mathrm{pH}$ in the range of physiological $\mathrm{pH}$ "acid mantle" the skin or also called $\mathrm{pH}$ balance, which ranges from 4.5 to 6.5 , and still in the scalp $\mathrm{pH}$ range, i.e., between 4,0 to $5.8 .^{25,26}$

Treatment of hair loss and thinning from natural product was widely needed. Proanthocyanidin from grape seeds stimulated the proliferation of hair follicle cells of mice in vitro and stimulate hair growth cycle of the telogen phase to anagen phase in vivo. ${ }^{8}$ Root extract of Sophora flavescens has been reported to stimulate hair growth. ${ }^{8-27}$

In this study, formula II and III, each containing $0.5 \%$ and $1 \%$ of ethyl acetate fraction have faster hair growth than positive control (Figure 1). The mechanism of hair growth from the ethyl acetate fraction is still unclear, but the activity of hair growth resulting from the ethyl acetate fraction N. scutellarium leaves is suggested due to flavonoids. Based on several studies, flavonoids contribute to the activity of hair growth by strengthening the walls of capillaries in the hair follicles, as well as improve blood circulation to nourish hair follicles that can increase hair growth..$^{7-9}$ Other studies also shown that flavonoids can shorten the telogen phase and can prolong the anagen phase. Based on research, minoxidil can prolong the anagen phase by extending the dermal papilla cell survival in the hair follicles by increasing proliferation and anti-apoptotic effects that can stimulate hair growth in the anagen phase. ${ }^{28}$ The role of flavonoids on the activity of hair growth is caused by several factors hair growth, such as insulin-like growth factors-1 (IGF-1), vascular endothelial growth factors (VEGF), keratinocyte growth factors (KGF), and hepatocyte growth factors (HGF), these factors have the effect of stimulating hair growth. ${ }^{8,9-27}$

In this study, the hair tonic on the formula III has a larger diameter than the positive control and has hair cuticle composed regularly and overlap (Figure 4). Some research suggests that healthy hair is observed with SEM (Scanning Electron Microscope) can be seen clearly has the hair cuticle smooth edges, patterns of cuticle layer to are arranged neatly to the inside of the hair seemed protected. ${ }^{25,29}$ Meanwhile, damaged hair has cuticle edges were chipped or loose. If the hair cuticle is almost completely peeled off, will make cortex layer is exposed, for example, the branched hair ends and hair fragile. ${ }^{25}$

\section{CONCLUSION}

Based on the results of this research concluded that the ethyl acetate fraction of Nothopanax scutellarium leaves could mild irritate the membranes chorioallantois and hair tonic preparations with the concentra- 
tion of $0.5 \%$ and $1 \%$ have hair growth activity the faster and can enlarge the diameter of the hair compared to the positive control.

\section{AKNOWLEDGEMENT}

This work financially was supported by Directorate of Higher Education, Ministry of Technology Research and Higher Education, Republik of Indonesia via Hibah PUPT 2015.

\section{CONFLICT OF INTEREST}

There is no conflict of interest.

\section{REFERENCES}

1. Rathi V, Rathi JC, Tamizharasi S. Development and evaluation of polyherbal formulations for hair growth potential. Pharmacognosy Research. 2009;1(4):234.

2. Zhang Y, Han L, Chen SS, Guan J, Qu FZ, et al. Hair growth promoting activity of cedrol isolated from the leaves of Platycladus orientalis. Biomedicine \& Pharmacotherapy. 2016;83:641-7. https://doi.org/10.1016/j.biopha.2016.07.022; PMid:27459121.

3. Sun YN, Cui L, LiW, Yan XT, Yang SY, et al. Promotion effect of constituents from the root of Polygonum multiflorum on hair growth. Bioorganic \& medicinal chemistry letters. 2013;23(17):4801-5. https://doi.org/10.1016/j.bmcl.2013.06.098; PMid:23896496.

4. Heyne K. Tumbuhan Berguna Indonesia. Jakarta: Yayasan Sarana Wana; 1987. (in Bahasa)

5. Handojo Y. Physical stability and hair growth promoting activity of Nothopanax scutellarium Merr leaves extract gel. 2011.

6. Sholikhah N. Efek campuran ekstrak daun Teh (Camellia sinensis L.) dan daun Mangkokan (Nothopanax scutellarium Merr.) terhadap pertumbuhan rambut kelinci jantan. 2008. (in Bahasa)

7. Kobayashi N, Suzuki R, Koide C, Suzuki T, Matsuda H, et al. Effect of leaves of Ginkgo biloba on hair regrowth in $\mathrm{C} 3 \mathrm{H}$ strain mice. Yakugaku zasshi: Journal of the Pharmaceutical Society of Japan. 1993;113(10):718-24. https://doi. org/10.1248/yakushi1947.113.10_718; PMid:8254481.

8. Takahashi T, Kamiya $\mathrm{T}$, Yokoo Y. Proanthocyanidins from grape seeds promote proliferation of mouse hair follicle cells in vitro and convert hair cycle in vivo. ACTA DERMATOVENEREOLOGICA-STOCKHOLM-. 1998;78:428-32.

9. Awe EO, Makinde JM. The hair growth promoting effect of Russelia equisetifor mis (Schclect\&Chan). Journal of Natural Products (India). 2009;2:70-3.

10. Shah M, Kabir H, Hossain MM, Kabir I, Rahman M, et al. Phytochemical screening, antioxidant, thrombolytic, $\alpha$-amylase inhibition and cyto toxic activities of ethanol extract of Steudnera colocasiifolia K. Koch leaves. J Young Pharm 2016;8(4):391-7. https://doi.org/10.5530/jyp.2016.4.15.

11. Mun'im A, Ramadhani F, Chaerani K, Amelia L, Arrahman A. Effects of gamma irradiation on microbiological, phytochemical content, antioxidant activity and inhibition of angiotensin con- verting enzyme (ACE) activity of Peperomia pellucida (L.) Kunth. J Young Pharm 2017;9(1):118-21.

12. Steiling $W$, Bracher $M$, Courtellemont $P$, De Silva O. The HET-CAM, a useful in vitro assay for assessing the eye irritation properties of cosmetic formulations and ingredients. Toxicology in vitro. 1999;13(2):375-84. https://doi.org/10.1016/ S0887-2333(98)00091-5.

13. Cazedey EC, Carvalho FC, Fiorentino FA, Gremião MP, Salgado HR. Corrositex $₫, B C O P$ and HET-CAM as alternative methods to animal experimentation. Brazilian Journal of Pharmaceutical Sciences. 2009:45(4):759-66. https://doi. org/10.1590/S1984-82502009000400021.

14. Rajpal Deshmukh G, Hema Kumar K, Suresh Reddy PV, Srinivasa Rao B, Venkata Satish Kumar C. Evaluation of eye irritation potential of aqueous leaf extract of Achyranthes aspera by in vitro and in vivo method. ISRN toxicology. 2012 https://doi.org/10.5402/2012/693489; PMid:23724295 PMCid:PMC3658502.

15. ICH. Stability Testing of New Drug Substances and Products Q1A(R2). Int Conf Harmon. 2003:24.

16. Harry RG. Harry's Cosmeticology $8^{\text {th }}$ ed. (Rieger MM, ed.). New York: Chemical Publishing Co Inc; 2010

17. Yoon Jl, Al-Reza SM, Kang SC. Hair growth promoting effect of Zizyphus jujuba essential oil. Food and chemical toxicology. 2010;48(5):1350-4. https://doi. org/10.1016/j.fct.2010.02.036; PMid:20206225.

18. Andarwulan N, Kurniasih D, Apriady RA, Rahmat H, Roto AV, et al. Polyphenols, carotenoids, and ascorbic acid in underutilized medicinal vegetables. Journa of Functional Foods. 2012;4(1):339-47. https://doi.org/10.1016/j.jff.2012.01.003.

19. 19. Yadav DK, Ali M, Ghosh AK, Kumar B. Isolation of flavonoid from Abies webbiana leaves and its activity. Pharmacognosy Journal. 2016;8(4).

20. 20. Chen D, Landis-Piwowar KR, Chen MS, Dou QP. Inhibition of proteasome activity by the dietary flavonoid apigenin is associated with growth inhibition in cultured breast cancer cells and xenografts. Breast Cancer Research. 2007;9(6):R80. https://doi.org/10.1186/bcr1797; PMid:18300387 PMCid:PMC2246179.

21. Kamimura A, Takahashi T. Procyanidin B-3, isolated from barley and identified as a hair-growth stimulant, has the potential to counteract inhibitory regulation by TGF- $\beta 1$. Experimental dermatology. 2002:11(6):532-41. https://doi.org/10.1034/ j.1600-0625.2002.110606.x; PMid:12473061.

22. Herman A, Herman AP. Mechanism of action of herbs and their active constituents used in hair loss treatment. Fitoterapia 2016;114(6):18-25. https://doi. org/10.1016/j.fitote.2016.08.008; PMid:27552901.

23. Wih LW, Ranti AR, Wasitaatmadja SM, Suryaningsih, Junardy FD M. Penelitian bahan pencerah dan pelembab kulit dari tanaman Indonesia. Majalah IImu Kefarmasian 2009;4:1-8. (in Bahasa)

24. Ansel H. Pengantar Bentuk Sediaan Farmasi (Trans). $4^{\text {th }}$ ed. Jakarta: UI-Press, Jakarta; 1989

25. Mitsui T. New Cosmetic Science. Amsterdam: $1^{\text {st }}$ ed. Amsterdam; 1997.

26. Barel AO, Paye M MH. Handbook of Cosmetic Science and Technology. 4th ed. New York: Informa Healthcare; 2014

27. Roh SS, Kim CD, Lee MH, Hwang SL, Rang MJ, et al. The hair growth promoting effect of Sophora flavescens extract and its molecular regulation. Journal of dermatological science. 2002;30(1):43-9. https://doi.org/10.1016/S09231811(02)00060-9.

28. Han JH, Kwon OS, Chung JH, Cho KH, Eun HC, et al. Effect of minoxidil on proliferation and apoptosis in dermal papilla cells of human hair follicle. Journal of dermatological science. 2004;34(2):91-8. https://doi.org/10.1016/j.jdermsci.2004.01.002; PMid:15033191.

29. Lim SN. A Study of Hair Damage by Magic Straight Perm. Applied Microscopy. 2012;42(3):129-35. https://doi.org/10.9729/AM.2012.42.3.129.

Article History: Submission Date : 09-02-2017; Revised Date : 04-05-2017; Acceptance Date : 28-05-2017

Cite this article: Rifkia V, Jufri M, Mun'im A. Hair Growth Promoting Activity of Nothopanax scutellarium Merr. Leaves. J Young Pharm. 2017;9(3):436-40. 